\title{
Assessment of Green Open Space in the Transit-Oriented Development Area in Jakarta
}

\author{
T Endangsih ${ }^{1,2, *}$, B Prayitno ${ }^{3}$, A Kusumawanto ${ }^{3}$ \\ ${ }^{1}$ Architecture Study Program, Faculty of Engineering, Budi Luhur University, Indonesia \\ ${ }^{2}$ Doctoral Program, Department of Architecture and Planning, Faculty of Engineering, Universitas Gadjah Mada, Indonesia \\ ${ }^{3}$ Departement of Architecture and Planning, Faculty of Engineering, Universitas Gadjah Mada, Indonesia
}

Received June 11, 2021; Revised December 10, 2021; Accepted December 23, 2021

\section{Cite This Paper in the following Citation Styles}

(a): [1] T Endangsih, B Prayitno, A Kusumawanto, "Assessment of Green Open Space in the Transit-Oriented Development Area in Jakarta," Civil Engineering and Architecture, Vol. 10, No. 1, pp. 1 - 11, 2022. DOI: 10.13189/cea.2022.100101.

(b): T Endangsih, B Prayitno, A Kusumawanto (2022). Assessment of Green Open Space in the Transit-Oriented Development Area in Jakarta. Civil Engineering and Architecture, 10(1), 1 - 11. DOI: 10.13189/cea.2022.100101.

Copyright $\odot 2022$ by authors, all rights reserved. Authors agree that this article remains permanently open access under the terms of the Creative Commons Attribution License 4.0 International License

\begin{abstract}
The Jatinegara Station area has developed as a commercial area causing the surrounding residential areas to develop into dense settlements and have limitations in providing facilities and infrastructure, especially green open spaces. Along with the increasing intensity of commercial activities, this has an impact on changing green open spaces into built-up land. The purpose of this study was to examine the existing condition of green open space in the Jatinegara TOD area and then compare it with the standards set by the local government. The results of this comparison are used to provide input on the design of green open spaces in the research area. This goal is achieved by using a quantitative approach. The analysis of the need for green open space is calculated based on the standard of $30 \%$ of the total area. The need for green open space is $20 \mathrm{~m}^{2}$ per person and the Gerarchis method is used to calculate the need for green space based on oxygen demand. The analytical method used in this research is descriptive quantitative analysis. As the first step is to identify the characteristics of green open space, analyze the availability of green open space and its form and typology. Based on the results of the study, it can be concluded that the availability of green open space affects the environmental quality of the TOD area. The form and typology of green open spaces found in the study area are urban forest green open spaces and sub-district environmental parks. Therefore, the existence of green open spaces needs to be maintained through the development and arrangement of green open spaces by taking into account the types of vegetation that can absorb $\mathrm{CO}_{2}$.
\end{abstract}

Keywords Gerarkis, Total Population, Area, $\mathrm{O}_{2}$, Green Open Space

\section{Introduction}

The growth of big cities in Indonesia at this time tends to be urban sprawl, which results in further travel and longer travel times. This growth is experienced by the City of Jakarta as a Metropolitan City and it's a satellite city which is currently in the process of becoming a Megapolitan City, so that it will cause environmental problems that are very diverse and complex, one of which is air pollution as a result of the use of motorized vehicles as the main means of transportation, be it work, school, or shopping. Where they live outside Jakarta with their daily activities or activities carried out in Jakarta. Thus the transportation of Jakarta and its surrounding satellite cities form a very close dependence and connection. Based on the Jakarta report in 2020 figures, the population of DKI Jakarta reached 10.56 million, an increase of $9.9 \%$ compared to the previous census results in 2019. If population growth is not controlled, the need for facilities will be even higher. Physical development is towards the maximum, while on the other hand, the development of open space is towards the minimum, thus changing the face of the whole city. The direct result of the imbalance between the built environment (built) and the protected environment (nature) causes a decrease in the quality of the urban environment 
(environmental degradation) [1]. Environmental problems that arise include air pollution, congestion, public health, and security [2]. Apart from these various problems, land availability also arises as a result of high population growth [3].

Land use planning is considered to have an important role in overcoming the problem of land availability in urban areas, namely by applying the concept of a transit-oriented development area [3][4]. Transit-Oriented Development (TOD) is a concept that combines land-use and transportation modes so that this concept can become a recommendation in efforts to develop sustainable urban areas [5][2]. The presence of the TOD area concept in urban development provides various benefits such as reduced congestion rates, reduced air pollution increased energy use efficiency, and most importantly increased land-use efficiency in urban areas [6]. The concept of the TOD area is also able to create a cultural community for walking and cycling, as well as providing green open spaces [7][8]. This happens because the TOD area has the principles of density, diversity, design, distance, and purpose [9].

Land use planning is considered to have an important role in overcoming the problem of land availability in urban areas, namely by applying the concept of transit-oriented development areas [10][4]. TOD is a concept that combines land use and transportation modes, so that this concept is able to become a recommendation in efforts to develop sustainable urban areas [11][12][2].

In Jakarta, the TOD study focused on environmental carrying capacity and land use typology [13][7]. In Surabaya, the TOD study focuses on the area's function as a mitigation of greenhouse gases [14]. In Depok, the study on TOD focuses on the actual conditions of the TOD index [15]. However, studies on TOD are still not in great demand by academics in Indonesia especially studies that focus on environmental models of TOD areas based on their urban designs. To determine the environmental model of the TOD area to provide green open space (RTH), it is necessary to calculate the need for green open space based on area size, population, and $\mathrm{O}_{2}$ needs.

Green open space is a part of urban space that serves to create visual comfort [16]. In the 2007 regulation of the ministry of public works, the requirement for green open space in each city must be $30 \%$ of the city's area. This is because green open spaces in every city have aesthetic, sociological, economic, educational, and other functions [17]. In its journey, the city will experience rapid development due to the dynamics and increase in population, socio-economic changes, and interactions with other areas that will certainly affect the green open space. If green open space is not controlled, then the amount of green open space will be less and there will be an environmental imbalance. The area of green open space will decrease every year, this is due to changes in the function of previously open land turning into urban infrastructure development areas such as buildings, toll roads, industry, and housing. Therefore, the development of green open space is the obligation of every city because it has a role as a place to play/entertainment, socialize, and has an ecological role such as absorbing rainwater, absorbing air pollution, selecting ecosystems, and controlling floods. Therefore, green open space is an important part of the development and planning of a city. The main function of green open space is to ensure comfort and environmental sustainability.

This study was conducted with the aim of assessing the current green space in the TOD area and comparing it with the standards required to obtain the Total $\mathrm{O}_{2}$ Needs in the DKI Jakarta TOD Area. This study also tries to design an environmental model of the TOD area based on each component of the urban design. This study was conducted based on the study variables used by Strong, Ozbek, Sharma, \& Akalp, namely 13 successful factors for developing the TOD area [18]. However, this study only uses urban design variables that are relevant in the case of the TOD area in Jakarta, namely green open space. Green open space plays an important role in the TOD area the component as a facility that has a public orientation that is able to form community social interactions, as well as land conservation as a symbol of environmentally friendly areas [19][20][21][22].

This research is expected to be a reference and comparison for determining the need for green open space, especially for urban areas that experience the same environmental problems. In addition, this research is expected to be a source of information for the public regarding the need for green open space so that it can be a reference for handling environmental problems in the TOD area of Jatinegara Station as a result of the rapid development of the city. The results of the study can be used as a consideration for the East Jakarta Regional Government to determine the area of green areas and the location of green open spaces that can be developed in urban areas.

\section{Literature Review}

\subsection{TOD Concept}

In 1992, the city of San Diego has adopted the concept of an urban mobility planning program which means a concept designed to make the efficient movement of people from one place to another within the walking distance of transit stops and central commercial areas. This concept came to be known as TOD (Transit Oriented Development) and continued to be developed because it proved successful in creating multi-purpose areas that increase population mobility [23]. According to Purwantiasning, TOD is defined as a multi-purpose community in an average transit reach of about 2000 steps in the distance between a public 
transport stop and a commercial center [24]. In the TOD area, there are housing, offices, retail, open spaces, and other public facilities with a friendly environment for the basis for public transportation such as pedestrians, bicycles, motorbikes or cars.

In the process of developing a TOD-based area, it is necessary to know the main characteristics that characterize the application of the TOD concept. These characteristics are described in more detail into the principles and indicators of the TOD concept. These principles and indicators are extracted from several kinds of literature formulated by institutions of urban development and transportation activists such as the Florida Department of Transportation (TCRPC), Institute for Transportation and Development Policy (ITDP) dan Calthorpe Associates. The following are the principles and indicators of the concept TOD [25]: 1) Density or densify in the formation of dense and dense patterns and spatial plans, by emphasizing the vertical growth of the city (densification) rather than the horizontal growth of the city (sprawl). According to TCRP, the density level of occupancy or property is an indicator that can explain the principle of density [26]. Meanwhile, ITDP tends to pay attention to the level of land use density, referring to the basic building coefficient and building floor coefficient [27]. The density of land use will bring various activities closer so that the use of public transportation modes can be maximized. 2) Land-Use Mixed aims to support mobility efficiency and increase the livability of the area by integrating housing with places of work, shopping, and schools. The mixing principle aims to bring related land uses closer so that it will encourage walking and cycling activities in the surrounding community [25]. TCRP divides the mixed-uses indicator into two things, namely the number of mixed-uses land use and the presence of retailers with various service scales [26]. 3) Pedestrian paths and bicycle lanes play an important role in shaping the culture of a society that is environmentally friendly and low in motor vehicle use [28][29][8]. 4) Mix-landuse plays an important role in supporting people's lives such as housing, offices, shopping, and others [20]. Green open space also plays an important role in the TOD area component as a facility that has a public orientation that is able to form community social interactions, as well as land conservation as a symbol of environmentally friendly areas [21]. Transit-Oriented Area, hereinafter referred to as TOD Area, is an area defined in the spatial plan as a centralized area for intermodal and intermodal integration within a radius of 400 (four hundred) meters to 800 (eight hundred) meters from the transit node of mass public transport modes that have a mixed and dense space utilization function with medium to high intensity of space utilization [30].

\subsection{Green Open Space}

Based on the National Defense Agency in Regulation of the Minister of Agrarian Affairs and Spatial Planning Number 16 of 2017 it is stated that the design of public spaces are viewed from the area of development carried out such as making plazas (open areas), parks, and street views [30]. Public space areas in development are useful for improving the quality of life and environmental resilience [31]. In general, public open space (open space) in urban areas consists of green open space and non-green open space [32]. The role and function of green open space specified in the Minister of Internal Affairs Instruction no. 4 of 1988, which states green open space where population is dominated by either natural reforestation or cultivation as ecology function and support urban area. The role and function of green open space specified in Regulation of the Minister of Public Works No. 5 of 2008 article 1 states green open space which states "green open space is spaces in the city or the wider region, either in the form of the area or elongated area/lane where its use more open without buildings. Green open space is the total area covered by green plants in a specific unit area either naturally or cultivated. Open space can be used for city ventilation, street, sidewalk, green open space, and etc. It also can be interpreted as an interaction space such as the zoo, recreation park.

\subsection{Public Space Quality}

Pedestrian and bicycle-friendly areas are defined not only by the urban structure but also by the quality of infrastructure and environmental design. The character of space, its appearance, and feel are also relevant in the relationship between the built environment and travel [33]. This can affect perceptions and change travel behavior. Having a walkable area around the transit stop, as already mentioned, is critical to the success of TOD. Walking is the most natural, affordable, healthy, and clean mode of travel for short distances, and an essential component of most transit trips. As such, walking is a fundamental building block of sustainable transport [34]. To make walking attractive to transit users and neighborhood residents, neighborhoods must be attractive by prioritizing good infrastructure, safety, active and vibrant pedestrian areas, and comfort levels [33]. Cycling friendly environment to encourage people to use this mode of transportation is an alternative to short-distance travel, mostly about safety and infrastructure. Related metrics are the completeness and connectivity of the cycling network, cycling safety infrastructures such as bike paths and lanes, or the supply of bicycle parking at transit stops and buildings.

\subsection{TOD and Open Space}

Most of the literature consulted covering some of the TOD guidelines on urban design did not mention any specific provisions regarding open public spaces as part of an ideal urban structure to encourage TOD. From the 
literature, Calthorpe's 1993 vision does emphasize that public use, parks, and squares are necessary for environmental success. He stated that "TOD structures are built around accessible and convenient public facilities and spaces" [35]. These spaces will then help to create a "strong sense of community, participation, identity, and friendliness". The role of parks and squares is to act as a place of meeting, recreational activities. They further facilitate "views and connections to streets and other public spaces and buildings", a view that the design elements must reinforce [35]. As seen in its TOD schematic, it even includes a "Public/Open Space" adjacent to the transit stop location as part of a key element of TOD. Where the open center location of the recreation space will benefit by being next to the city and transit services [35]. Development of Transit-Oriented Areas related to green open space refers to the principle of increasing the proportion of Green Open Space and the green index; Provision of public open space that can be accessed by all communities [36].

\section{Research Methods}

This research was conducted in the transit area of Jatinegara Station, East Jakarta. The transit area of Jatinegara Station is one of the areas located in potential areas, among others; East Jakarta trade center, namely Jatinegara wholesale market (Mester market), agate trading center, animal market, and others. The area around the transit location of Jatinegara Station in the Spatial plans DKI Jakarta 2030 is planned to become a secondary area for office, trade, and service activities.

This research uses a field study method by observing the existing conditions of the research area, besides that it also uses a calculation method. The calculation method is used to calculate the need for green open space based on population density and area the area can be calculated through the standard requirement for green open space; which is $30 \%$ of the total area. To calculate the need for green open space based on oxygen demand using the Gerarkis method.

The tools and materials used in this research are stationery and computers that are useful for the process of data collection and data analysis, as well as cameras used to document survey results in the area around Jatinegara Station. The data used in this study include biophysical data in the form of area, population data, and a number of vehicles in East Jakarta obtained from the Central Jakarta Statistics Agency 2020. In addition to these data, photographs of open spaces at the research site are required, and land use maps as the basis for analyzing existing conditions and green open space assessment.

Analysis of the calculation of the need for green open space can be carried out by considering the area, population, and oxygen needs of the population [37][38].
Calculation of the need for green open space based on area and population is calculated by referring to the Spatial Planning Law Number 26 of 2007 and the Regulation of the Minister of Public Works Number 05/M/PRT/2008. Meanwhile, the calculation of the area of green open space is based on the oxygen needed by humans with the parameters of the type of vehicle, the number of people, and the standard of oxygen consumption. Meanwhile, the calculation of the need for green open space based on $\mathrm{O}_{2}$ needs is calculated using the Gerarkis method [37][38]. The calculation is based on the number of residents and the number of motorized vehicles. The formula for the Gerarchical method is as follows:

$$
\mathrm{Lt}=\frac{\mathrm{Pt}+\mathrm{Kt}+\mathrm{Tt}}{(54) x(0.9375)} m^{2}
$$

Where $=$

$\mathrm{Lt}=$ is the area of green open space for the year $(\mathrm{t})$

$\mathrm{Pt}=$ is the amount of oxygen demanded year to $(\mathrm{t})$

$\mathrm{Tt}=$ is the amount of morning oxygen demand of motorized vehicles $(\mathrm{t})$

$\mathrm{Kt}=$ is the amount of oxygen demand for motor vehicles in the year $\mathrm{t}$

$54=$ is a constant indicating that $1 \mathrm{~m}^{2}$ of land area, produces 54 grams of plants per day

$0.9375=$ that is a constant indicating that $1 \mathrm{~m}^{2}$ of dry plants produces 0.9375 grams of oxygen

The standard of oxygen demand is carried out in order to know the value of $\mathrm{O}_{2}$ needed and the carbon dioxide released so as to provide comfort and health for the surrounding community. The oxygen demand standard and minimum power classification of vehicles are shown in Table 1 and Table 2 below:

Table 1. Provisions for $\mathrm{O}_{2}$ Needs and Fuel Consumption

\begin{tabular}{|c|c|c|}
\hline $\begin{array}{c}\text { Human } \mathrm{O}_{2} \text { Consumption } \\
\text { Per Day }\end{array}$ & \multicolumn{2}{|c|}{$\begin{array}{c}840 \\
\text { (gram / day) }\end{array}$} \\
\hline \multirow{2}{*}{$\begin{array}{l}\text { Average fuel consumption ( } \mathrm{kg} / \mathrm{PS} \\
\text { hour) }\end{array}$} & Fuel & 0.21 \\
\hline & Diesel & 0.16 \\
\hline \multirow{2}{*}{$\begin{array}{l}\text { Oxygen requirements per } 1 \mathrm{~kg} \text { of } \\
\text { fuel }\end{array}$} & Fuel & 2.77 \\
\hline & Diesel & 2.86 \\
\hline
\end{tabular}

Source: Minister of Public Works Regulation Number: 05/PRT/M/2008

Table 2. Classification and Minimum Power of Vehicles

\begin{tabular}{cc}
\hline Classification & Minimum Power (PS) \\
\hline Motorcycle & 1 \\
\hline Car & 20 \\
\hline Truck Vehicles & 50 \\
\hline Bus Vehicle & 100 \\
\hline
\end{tabular}

Source: Minister of Public Works Regulation Number: 05 /PRT/M/2008 


\section{Analysis and Discussion}

The Jatinegara Station area is a prospective economic area, or an area that has a center of trade and service activities in Jatinegara, which is supported by the existing function of the Jatinegara traditional market (Meester Market), Jatinegara Plaza (Mall), Rawa Bening Market and Akik craft center, shop houses, hotels, and so on. Due to its strategic location, the Jatinegara Triangle Region acts as a transitional area between the trade and service areas along the main road corridor and the surrounding residential areas. In accordance with the directions of the 2010 DKI Jakarta City Spatial Plan and the Jatinegara Subdistrict Detail Spatial Plan, the macro designation plan for the Jatinegara triangle area is expected to encourage the growth of land use for mixed functions, with the dominance of public buildings or office works and trade works.

The Jatinegara TOD development area has a green open space plan consisting of three types, namely the green line zone, the cemetery zone, and the city/environmental park zone. In 2019, the research area was $153.86 \mathrm{Ha}$, or $60 \%$ of the research area. The Land island is covered by buildings with an area of 139.10 ha or about $90 \%$ and an open land area of 14.76 ha or $9.5 \%$ of the research area. Based on these data, green open space in the study area is only 14.20 hectares or $9.22 \%$. It means that the green open space in the planning area is still not enough because it has not reached $30 \%$. Therefore, there needs to be a recommendation that can encourage local governments to provide green open space plans of up to $30 \%$. Distribution of green open space development plans in the TOD area The following results of observations of green open spaces in the planning area are described in Figure 1, meanwhile, in the Urban Design Guide Line (UDGL) in the Jatinegara Triangle, there is a new open space that will be developed so that it can become a potential development. The guide image for green open space planning is explained in Figure 2.

Figure 1 shows the lack of green open space in the research location and the reforestation conditions in the study area have not been fully formed and lack of maintenance. If it is developed, it needs to be rearranged by following the pattern of outdoor space and its circulation. The types of reforestation plants are not only trees but also shrubs and ground cover plants. The green open space at the location is managed by the Regional Government, point 1 open space is not used properly, it should be an open space at the sub-district level that can be used for sports, children's play rooms and public open spaces, but is used as a fish market which is open from dawn. While the open space point 2 has the status of a City Forest Park which is equipped with a jogging track and play room, but it is underutilized because it is under a toll road and there is no parking space for vehicles in the area.

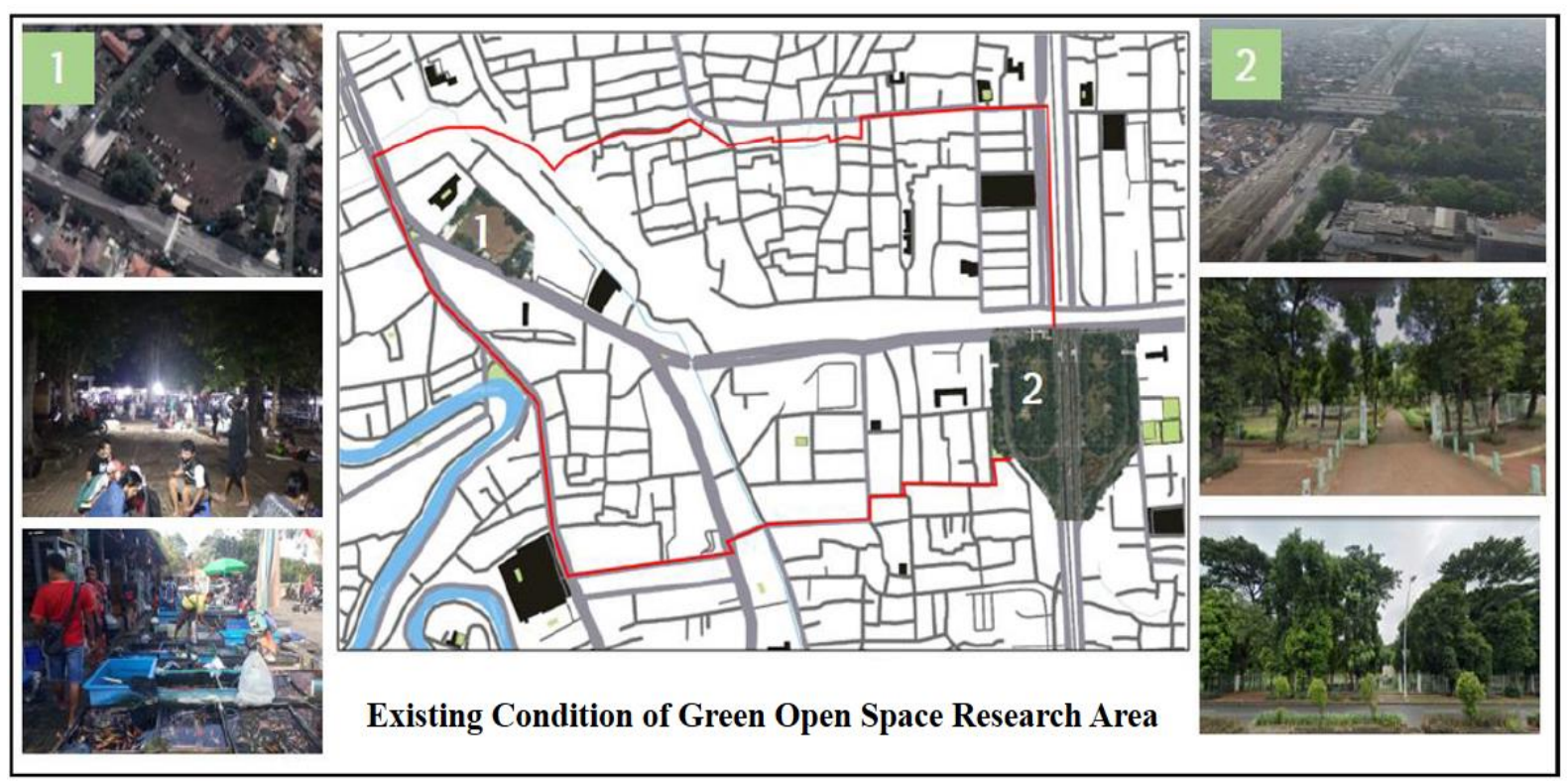

Source: www.Jakartasatu.go.id and processed by Researchers, 2020

Figure 1. The Area of Green Open Space Jatinegara Station TOD Area 
The research area is shown in Figure 2.

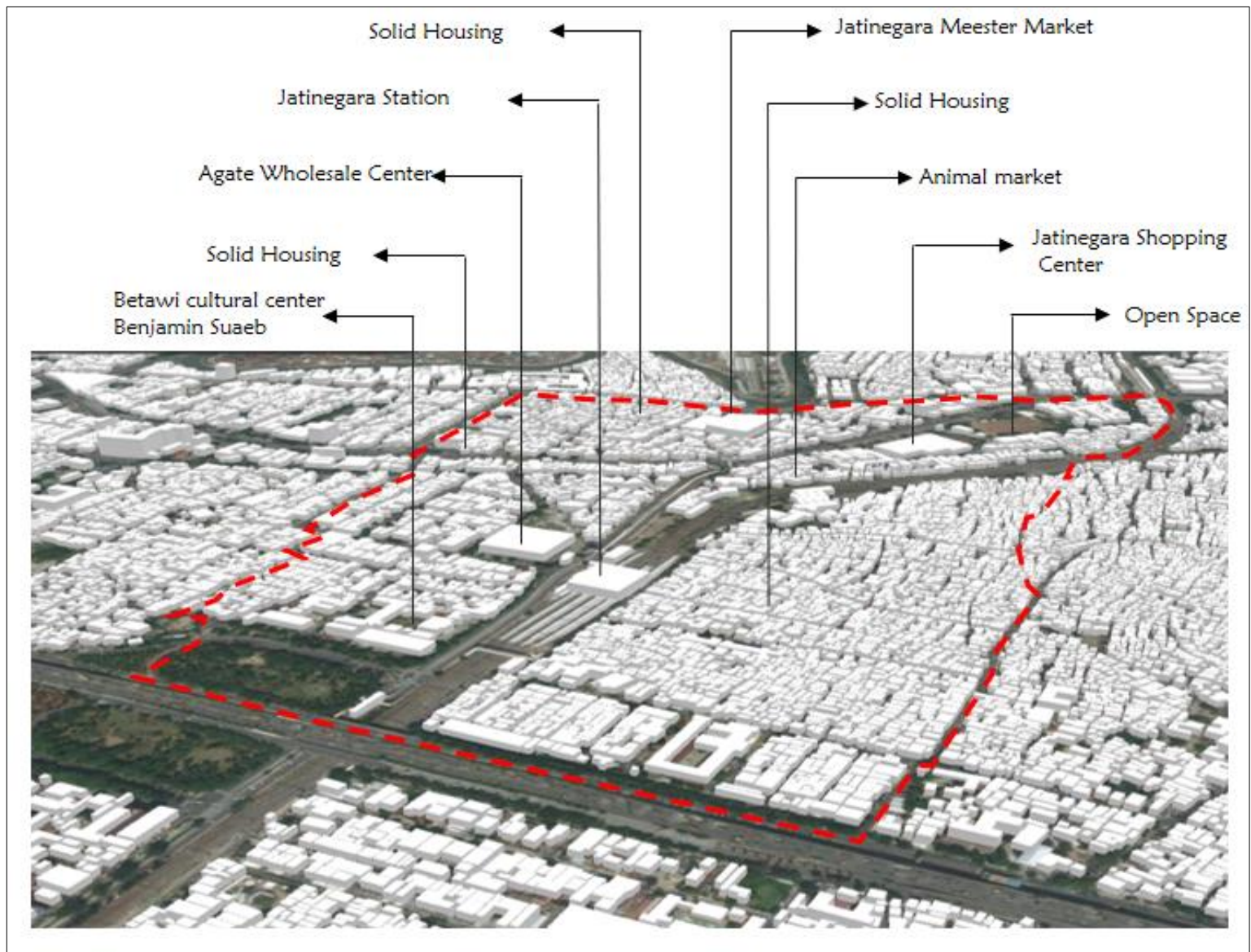

Source: www.Jakartasatu.go.id and processed by Researchers, 2020

Figure 2. Existing Conditions of the Research Area Scope

\section{Percentage of Land Use}

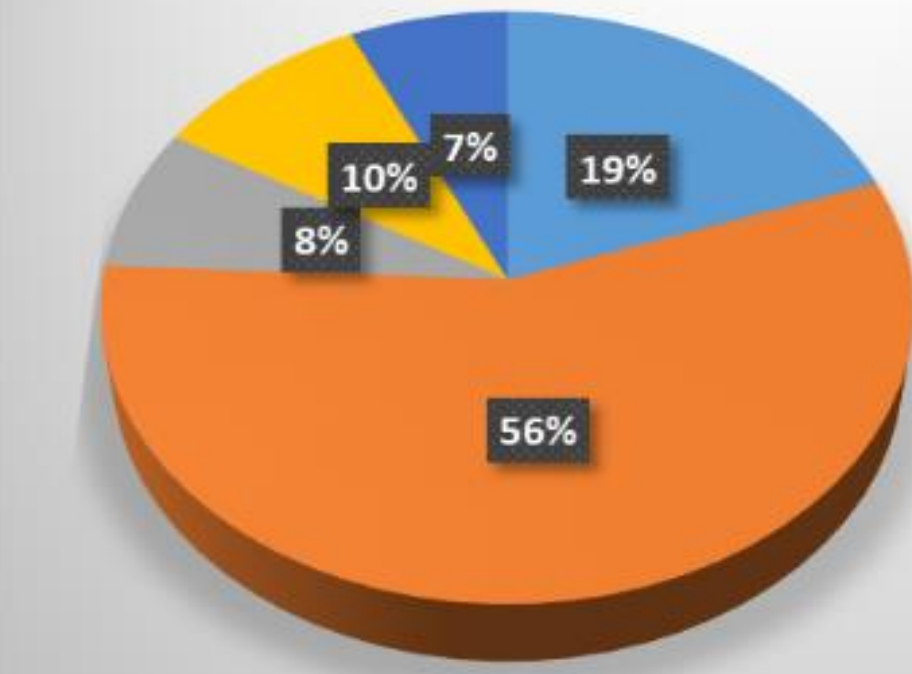

- Trade and services

Eccupancy

Government Office Facilities and Social Services

Ereen open space

- Street

Source: The results of the author's analysis based on data from Jakarta.go.id, 2019

Figure 3. Percentage of Land Use in the Study Area 
Based on the picture of the Detailed Spatial Plan for the research area (Jatinegara District, Matraman District, and Pulo Gadung District) in 2012-2030, Google Earth, and analysis of the survey results can be shown the data on land use in the research area in Figure 3.

Land use in the research area is dominated by residential functions by $56 \%$, commercial functions $19 \%$ (Mester Market, Animal market, Lippo Jatinegara plaza, precious stone market, and shops), social service facilities (schools, health services, places of worship), health and government offices as much as $8 \%$, and the function of green open space by $10 \%$. With the existing land use condition like this, it is not in accordance with the regional spatial plan, because the function should be dominated by trade-service and office functions, while the other functions as supporting facilities. The area of land used for green open space is also still far from the requirements set by the government, namely $30 \%$, therefore to meet the requirements it is necessary to plan open space areas both on a city, sub-district, village and housing complex scale.

\subsection{Green Open Space Needs Based on Area}

According to the Spatial Planning Law Number 26 of 2007 , the proportion of green open space in an area is $30 \%$ of the administrative area of the area. Table 3 shows the results of the analysis of the need for green open space in the study area.

From the results of the analysis and calculations in Table 3 , the required green open space (RTH) in the research area is $39,69 \mathrm{Ha}$ of $30 \%$ of the total area of the research area, while the existing green open space is currently $8,60 \mathrm{Ha}$ or $8,89 \%$ of the total area of the study area. These results indicate that the need for green open space based on the area in the study area is not fulfilled in that area still require green open space of 31,09 Ha. Therefore, it is necessary to add the area of green open space at the location by using a detailed urban spatial plan guide. The placement of new green open spaces adjusts to the land use map and the land-use intensity map. In the concept of developing the TOD area, green open space is one of the indicators of
TOD's success in terms of improving the quality of $\mathrm{O}_{2}$, providing space for interaction and socializing, and is beneficial for the sustainability of residential areas.

\subsection{Need for Green Open Space Based on Total Population}

The calculation of the need for green open space is carried out by referring to the Regulation of the Minister of Public Works Number 05/M/PRT/2008 that the need for comfort of the population towards open green space is $20 \mathrm{~m}^{2}$ per resident. Analysis of the need for green open space based on the population in the study area is shown in Table 4.

The results of the analysis in Table 4 show that the area of green open space based on the number of residents in the Station Transit Area, the calculation of the need for green open space based on the standard requirement of $20 \mathrm{~m}^{2} /$ person multiplied by the population of 36,164 people is $72,328 \mathrm{Ha}$. When compared with the need for green open space based on the standards of the ministerial regulation regarding the area of green open space of 30\% of the total TOD area of $39.69 \mathrm{Ha}$, this figure shows that the area of green open space based on the number of residents based on field observations has not been fulfilled. From the results of the comparison of the calculation of the need for green open space based on the area with the calculation of green open space based on the number of residents, there is still a shortage of green open space of 32,638 hectares. Therefore, it is necessary to add green open areas by rearranging existing ones and adding areas to other locations permitted by the local government as priority locations for green open spaces by taking into account the scale of service, functions of green open spaces, and types of vegetation. The results of this analysis show that the population greatly affects the area of green open space. This is indicated by the area of green open space based on the number of residents is greater than the area of green open space based on $30 \%$ of the TOD area.

Table 3. Analysis of Green Open Space Needs Based on the Area in the Study Area

\begin{tabular}{ccccc}
\hline No & Districts & Sub-District & Area (Ha) & $\begin{array}{c}\text { The green open space needed is 30\% } \\
\text { of the total area (Ha) }\end{array}$ \\
\hline \multirow{2}{*}{1} & \multirow{2}{*}{ Jatinegara } & Balimester & 29,20 & 7,43 \\
\cline { 3 - 5 } & Matraman & Rawa Bunga & 31,03 & 13,89 \\
\hline 2 & Total & Pisangan Baru & 36,51 & 18,37 \\
\hline & & & 96.74 & 39,69 \\
\hline
\end{tabular}

Source: Researcher Analysis, 2020 
Table 4. Analysis of Green Open Space Needs Based on the Population in the Transit Area at Jatinegara Station

\begin{tabular}{ccccc}
\hline \multirow{2}{*}{ No } & Districts & Sub-District & Total population & $\begin{array}{c}\text { Standard area of green open space 20 } \\
\mathbf{m}^{2} / \text { capita }\end{array}$ \\
\hline \multirow{2}{*}{1} & \multirow{2}{*}{ Jatinegara } & Balimester & 4.668 & 93.360 \\
\cline { 3 - 5 } & Matraman & Rawa Bunga & 8.460 & 169.200 \\
\hline 2 & Pisangan Baru & 23.036 & 460.720 \\
\hline & Total & 36.164 & 723.280 \\
\hline
\end{tabular}

Source: East Jakarta BPS Analysis and Figures, 2019

Table 5. The Number of $\mathrm{O}_{2}$ Human Needs in the TOD Area of Jatinegara Station in 2019

\begin{tabular}{|c|c|c|c|c|c|}
\hline No & Districts & Sub-district & Total population & $\begin{array}{c}\text { Human Oxygen } \\
\text { Consumption / day } \\
\text { (gram / day) }\end{array}$ & $\begin{array}{c}\text { Oxygen } \\
\text { consumption (gram } \\
\text { / day) } \\
\end{array}$ \\
\hline \multirow{3}{*}{1} & \multirow{3}{*}{ Jatinegara } & Balimester & 9.546 & \multirow{6}{*}{840} & 8018.64 \\
\hline & & Rawa Bunga & 4.482 & & 3764.88 \\
\hline & & Cipinang Besar Utara & 15.944 & & 13392.96 \\
\hline \multirow{2}{*}{2} & \multirow{2}{*}{ Matraman } & Pisangan Baru & 30.779 & & 25854.36 \\
\hline & & Utan Kayu Selatan & 5.467 & & 4592.28 \\
\hline 3 & Pulo Gadung & Pisangan Timur & 10.052 & & 8443.68 \\
\hline
\end{tabular}

Table 6. Oxygen Needs According to the Classification of Types of Motor Vehicles

\begin{tabular}{cccccc}
\hline $\begin{array}{c}\text { Transportation } \\
\text { type }\end{array}$ & $\begin{array}{c}\text { Minimum } \\
\text { power }(\mathbf{P s})\end{array}$ & $\begin{array}{c}\text { Fuel Requirement } \\
(\mathbf{K g} / \text { Ps) }\end{array}$ & $\begin{array}{c}\mathbf{O}_{2} \text { Needs Every } \\
\text { 1 Liter BB } \text { (kg) }\end{array}$ & $\begin{array}{c}\mathbf{O}_{2} \text { requirement } \\
(\mathbf{k g})\end{array}$ & $\begin{array}{c}\mathbf{O}_{2} \text { requirement } \\
(\text { gram / day })\end{array}$ \\
\hline $\begin{array}{c}\text { Two or three } \\
\text { wheels }\end{array}$ & 1 & 0,21 & 2,77 & 0,851 & 581,7 \\
\hline $\begin{array}{c}\text { Four wheels or } \\
\text { more }\end{array}$ & 20 & 0,21 & 2,77 & 11,63 & 11.634 \\
\hline & Total & & 12.21 & $12,215.7$ \\
\hline & Median & 6.105 & $6,107.85$ \\
\hline
\end{tabular}

Table 7. Amount of $\mathrm{O}_{2}$ Needs for Motorized Vehicle Riders in the TOD Area at Jatinegara Station

\begin{tabular}{|c|c|c|c|}
\hline Transportation type & $\begin{array}{c}\text { LHR (Average Daily Traffic) } \\
\text { (vehicles / day) }\end{array}$ & $\begin{array}{c}\mathrm{O}_{2} \text { requirement (gram / } \\
\text { day) }\end{array}$ & $\begin{array}{c}\text { Total } \mathrm{O}_{2} \text { Requirement (gram } / \\
\text { day) }\end{array}$ \\
\hline Two or three wheels & 28.142 & 581.70 & $16,370,201.4$ \\
\hline \multirow[t]{2}{*}{ Four wheels or more } & 3,965 & $11,634.00$ & $46,128,810$ \\
\hline & Total & & $62,499,011$ \\
\hline
\end{tabular}

Source: Authors' Analysis Based on Data from Minister of Public Works Regulation No: 05 / PRT / M / 2008

\subsection{Area of Green Open Space Based on $\mathrm{O}_{2}$ Needs}

The administrative data of the research area is $153.86 \mathrm{Ha}$ with a population of 76,270 people. To calculate the need for green open space based on $\mathrm{O}_{2}$ needs using the Gerarkis method, it is necessary to calculate the human oxygen demand per / day and the oxygen demand for motorized vehicle drivers per / day. Oxygen requirements (grams/day), namely:

$$
\begin{aligned}
& \text { Need for Oxygen }=840 \times 36.164 \\
& \quad=30.377 .760 \text { gram/Day }
\end{aligned}
$$

From the results of this analysis, it is known that the human oxygen demand per / day $(\mathrm{Pt})$ is $64,066,800$ grams / day and the oxygen demand for motorized vehicle drivers per day is 62,499,011 grams / day. The need for green open space is calculated using the Gerarchical method. The calculation is based on the number of residents and the number of motorized vehicles. The formula for the Gerarchical method is as follows:

$$
\begin{gathered}
\mathrm{Lt}=\frac{\mathrm{Pt}+\mathrm{Kt}}{(54) x(0.9375)} \mathrm{m}^{2} \\
\mathrm{Lt}=\frac{30.377 .760+62,499,011}{(54) x(0.9375)} \mathrm{m}^{2}
\end{gathered}
$$




$$
\begin{aligned}
& \text { Lt }=\frac{92.876 .771}{(54) x(0.9375)} \mathrm{m}^{2} \\
& \begin{aligned}
\mathrm{Lt} & =\frac{92.876 .771}{50,625} \mathrm{~m}^{2} \\
= & 1.834 .602,88 \mathrm{~m}^{2} \\
= & 183,46 \mathrm{Ha}
\end{aligned}
\end{aligned}
$$

So the area of green open space needed to be based on the need for $\mathrm{O}_{2}$ is $183.46 \mathrm{Ha}$. The results of the calculation of $\mathrm{O}_{2}$ requirements are strongly influenced by the number of residents and types of vehicles, therefore it is necessary to the redevelopment of land use and regulation of motorized vehicle lanes and reduce the use of private vehicles by using public transportation so that it will be in accordance with the benefits of TOD to improve environmental quality by using mass transportation, walking, cycling, and providing green open spaces for $\mathrm{CO}_{2}$ absorption and areas to interact and socialize. All of these TOD benefits are useful for city sustainability.

The analysis that has been carried out based on the area, population, and oxygen demand in this study resulted in : 1) The need for green open space based on $30 \%$ of the TOD area is $39.69 \mathrm{Ha}$; 2) The need for green open space based on $20 \mathrm{~m}^{2}$ per population of 36,164 people is $72,328 \mathrm{ha} ; 3$ ) The need for green open space based on the need for $\mathrm{O}_{2}$ by calculating the number of vehicles and the oxygen requirement for riders gram/day is 183.46 ha.

The need for green open space based on the area in the TOD area has not met applicable regulatory standards, while the need for green open space based on population and oxygen needs has also not been met. Based on the area, the Jatinegara TOD area still requires 31.09 hectares of green open space with a percentage of $21.112 \%$. The TOD area also lacks public park infrastructure for community activities such as playing, exercising, relaxing, and recreation. In addition, there is still a lack of green lines along the railway line and along the road.

The follow-up to the results of the analysis of the need for green open space based on the area, population, and oxygen demand is the arrangement of existing open spaces in the location and additions in other areas according to the direction of the DKI Jakarta spatial planning office. The planning of the green open space area is guided by the urban design guidelines for the Jatinegara triangle area. One of the alternative green open space design plans in the research area is shown in Figure 4.

Figure 4 shows the design plan for the arrangement and addition of green open space areas according to the urban design guideline for the Jatinegara Triangle Region. At number one it is planned as a sub-district scale park, number two is open space in the apartment area, number three is environmental green open space, number four is green open space along the river, number five is green open space on an environmental scale, number six is residential green open space, number seven All green open spaces are worth the road, and number eight is green open space with the function of City Forest.

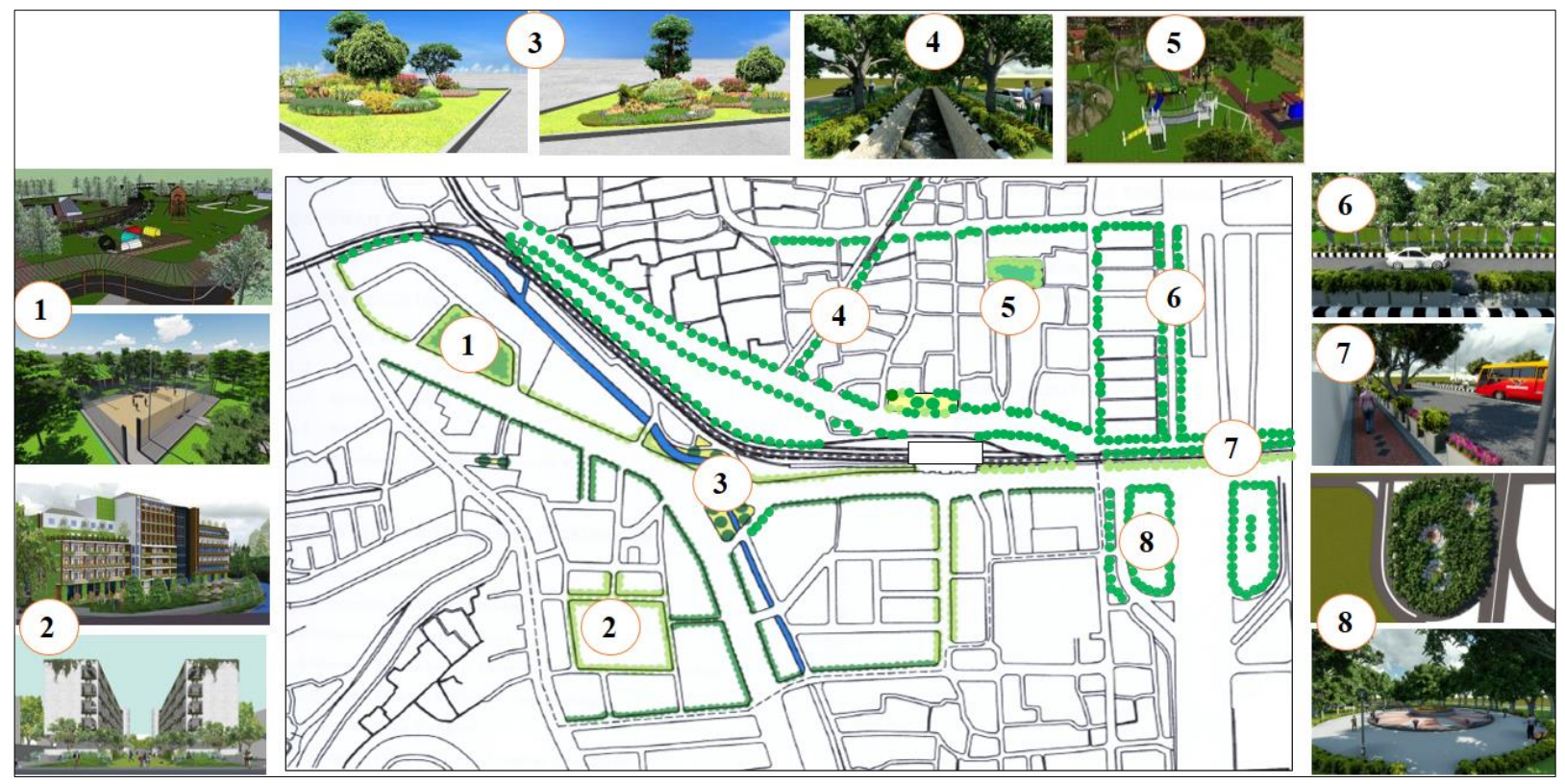

Source: Researcher Analysis, 2020

Figure 4. Design Plan for the Arrangement of Green Open Space Areas in the Research Area 


\section{Conclusions}

Based on the results of the study, it can be concluded that there is a relationship between green open space and environmental quality. The availability of green open space affects the level of environmental quality of the TOD planning area. The form and typology of green open space found in the study area are green open space, environmental parks, urban forest parks, and green lanes. Therefore, the existence of green open spaces needs to be maintained through the development of green open spaces in the smallest unit by local residents. In this case, the government's role is needed in determining the location for maintaining the existence of green open space which will experience a change in function into built-up land and proportion in a building.

From the results of the calculation of the need for green open space based on the TOD area at Jatinegara Station, it has not met applicable regulatory standards, while the need for green open space based on population and oxygen needs has been met. With the total area of the TOD area which has only reached $9.22 \%$, it still requires 36.92 hectares of green open space with a percentage of $20.78 \%$. In the TOD area, Jatinegara Station also lacks public park infrastructure for community activities such as playing, exercising, relaxing, and recreation.

Some suggestions that can be given regarding green open space in terms of urban planning are to increase the area of green open space in the TOD development area. The purpose of increasing the area of green open space is to meet the community's standard of comfort, which is at least $30 \%$ of the total area by taking into account the model and type of vegetation. Additional areas to protect urban conditions from pollution and environmental degradation are in line with the increasing population and ongoing development. But on the other hand, it is necessary to continue to protect and maintain the existing green open spaces. In addition, increase reforestation by inviting the community to plant at least one tree in each house to increase green open space.

The development of this research needs to be carried out as a scientific development of regional planning, not only assessing the condition of green open spaces in the TOD area, but also can be developed to a wider scale (Macro) namely the City area.

\section{REFERENCES}

[1] A. Komeily and R. S. Srinivasan, "A need for balanced approach to neighborhood sustainability assessments: A critical review and analysis," Sustain. Cities Soc., vol. 18, pp. 32-43, 2015.

[2] E. Trepci, P. Maghelal, and E. Azar, "Effect of Densification and Compactness on Urban Building Energy Consumption:
Case of a Transit-Oriented Development in Dallas, TX," Sustain. Cities Soc., vol. 56, pp. 1-2, 2019.

[3] L. Chen, X. Yang, L. Chen, R. Potter, and Y. Li, "A state-impact-state methodology for assessing environmental impact in land use planning," Environ. Impact Assess. Rev., vol. 46, pp. 1-12, 2014.

[4] X. Ma, X. Chen, X. Li, C. Ding, and Y. Wang, "Sustainable station-level planning: An integrated transport and land use design model for transit-oriented development," J. Clean. Prod., vol. 170, pp. 1052-1063, 2018.

[5] J. Li and H. Huang, "Effects of transit-oriented development (TOD) on housing prices: A case study in Wuhan, China," Res. Transp. Econ., vol. 80, pp. 1-5, 2020.

[6] D. Pojani and D. Stead, "Dutch planning policy: The resurgence of TOD," Land use policy, vol. 32, pp. 172-179, 2014.

[7] H. S. Hasibuan, S. Moersidik, R. Koestoer, and T. P. Soemardi, "Using GIS to integrate the analysis of land-use, transportation, and the environment for managing urban growth based on transit oriented development in the metropolitan of Jabodetabek, Indonesia," IOP Conf. Ser. Earth Environ. Sci., vol. 18, no. 1, pp. 1-6, 2014.

[8] D. S. Vale, "Transit-oriented development, integration of land use and transport, and pedestrian accessibility: Combining node-place model with pedestrian shed ratio to evaluate and classify station areas in Lisbon," J. Transp. Geogr., vol. 45, pp. 70-80, 2015.

[9] D. Jeffrey, C. Boulangé, B. Giles-Corti, S. Washington, and L. Gunn, "Using walkability measures to identify train stations with the potential to become transit oriented developments located in walkable neighbourhoods," J. Transp. Geogr., vol. 76, pp. 221-231, 2019.

[10] L. Chen, X. Yang, L. Chen, R. Potter, and Y. Li, "A state-impact-state methodology for assessing environmental impact in land use planning," Environ. Impact Assess. Rev., vol. 46, pp. 1-12, 2014.

[11] J. Li and H. Huang, "Effects of transit-oriented development (TOD) on housing prices: A case study in Wuhan, China," Res. Transp. Econ., vol. 80, pp. 1-15, 2020.

[12] H. Pan, Q. Shen, and C. Liu, "Transit-oriented development at the urban periphery," Transp. Res. Rec., vol. 1993, no. 2245, pp. 95-102, 2011.

[13] H. S. Hasibuan, R. Harmain, W. Berkademi, and I. P. Sari, "Support Capacity of Transit Oriented Development Areas in Lebak Bulus, DKI Jakarta Province," Plano Madani, vol. 7, pp. 174-184, 2018 .

[14] K. D. M. E. Handayeni, "TOD Best Practice: Lesson Learned for GHG Mitigation on Transportation Sector in Surabaya City, Indonesia,” Procedia - Soc. Behav. Sci., vol. 135 , pp. $152-158,2014$.

[15] J. Sulistyaningrum, S Sumabrata, “Transit Oriented Development (TOD) index at the current transit nodes in Depok City, Indonesia,” IOP Conf. Ser. Earth Environ. Sci., vol. 128, pp. 1-12, 2018.

[16] C. Fandeli, Kaharuddin, and Muklison, Urban Forestry. Yogyakarta: Faculty of Forestry UGM, 2004. 
[17] S. Samsudi, "Green Open Space Needs of Urban Spatial Planning in Surakarta City,” J. Rural Dev., vol. 1, pp. 1-9, 2010.

[18] K. C. Strong, M. E. Ozbek, A. Sharma, and D. Akalp, "Decision support framework for transit-oriented development projects," Transp. Res. Rec., vol. 2671, pp. 51-58, 2017.

[19] H. S. Hasibuan, T. P. Soemardi, R. Koestoer, and S. Moersidik, "The Role of Transit Oriented Development in Constructing Urban Environment Sustainability, the Case of Jabodetabek, Indonesia," Procedia Environ. Sci., vol. 20, pp. 622-631, 2014.

[20] M. Kamruzzaman, D. Baker, S. Washington, and G. Turrell, "Advance transit oriented development typology: Case study in brisbane, australia," J. Transp. Geogr., vol. 34, pp. 54-70, 2014.

[21] S. Shastry, "MSc Thesis Title : Spatial assessment of transit oriented development in Ahmedabad, India," University of Twente, 2010.

[22] J. H. Liu, J. Te Pai, and J. J. Lin, "Planning Strategy for Green Transit Oriented Development Using A Multi-objecitve Planning Model," Int. Rev. Spat. Plan. Sustain. Dev., vol. 6A, no. 1, pp. 35-52, 2018.

[23] W. Setiawan, "Reading The Urban Planning in Indonesia: A Journey Towards Sustainable Development," J. Sinektika, vol. 14, no. 2, pp. 257-268, 2014.

[24] A. W. Purwantiasning, "Understanding the Concept of Transit Oriented Development Through Proposed Project of Manggarai, Jakarta Selatan, Indonesia," in Proceeding of International Seminar and Workshop on Urban Planning and Community Development IWUPDC 2017: 18-22 September 2017, 2017, pp. 63-74.

[25] Muhammad Hidayat Isa, "Transit Oriented Development (TOD) Sebagai Solusi Alternatif Dalam Mengatasi Permasalahan Kemacetan Di Kota Surabaya," Surabaya, 2017.

[26] TCRP, Estimating the Benefits and Costs of Public Transit Projects: Cooperative Tcrp Oversight And Project Selection Committee Members Secretary. 2002.
[27] ITDP, “Annual Report 2015 ITDP Annual Report 2015," 2015.

[28] B. Griffiths and C. Curtis, "Effectiveness of Transit Oriented Development in Reducing Car Use: Case Study of Subiaco, Western Australia," Urban Policy Res., vol. 35, no. 4, pp. 391-408, 2017.

[29] M. L. Laham and R. B. Noland, "Nonwork trips associated with transit-oriented development," Transp. Res. Rec., vol. 2606, no. 1, pp. 46-53, 2017.

[30] Minister of Agrarian Affairs and Spatial Planning, Regulation of the Minister of Agrarian and Spatial Planning/Head of the National Land Agency of the Republic of Indonesia Number 16 of 2017 concerning Guidelines for the Development of Transit Oriented Areas. Jakarta, 2017.

[31] F. I. J. W. C. Trimarianto and I. W. Wiryawan, "Implementing Transit Oriented Development Principles in Designing Light Rail Transit Station in Bandung," J. Archit. Res. Des. Stud., 2020.

[32] N. Purnomohadi, Green Open Space as the Main Element of City Spatial Planning. Jakarta: Directorate General of Spatial Planning, 2006.

[33] R. Ewing and R. Cervero, "Travel and the Built Environment: A Synthesis," J. Transp. Res. Rec., vol. 1780, pp. 87-114, 2001.

[34] Institut for Transportation and Development (ITDP), "TOD Standard volume 2.1," New York: Despacio, 2014.

[35] P. Calthorpe, The Next American Metropolis: Ecology, Community and the American Dreams. New York: Princeton Architectural Press, 1993.

[36] Governor of the Special Capital Region of Jakarta, Regulation of the Governor of the Special Capital Region of Jakarta Number 67 of 2019 concerning the Implementation of Transit Oriented Areas. Jakarta, 2019.

[37] B. Gulo, "Analysis of the Need for Green Open Space (RTH) in Medan City," University of Northern Sumatra, 2008.

[38] J. Pancawati, "Analysis of the Need for Green Open Space in Tangerang City,” Bogor Agricultural Institute, 2010. 